\title{
Man and nature in the Confucian tradition: some reflections in the twenty-first century
}

CHUN-CHIEH HUANG*

\begin{abstract}
Amidst the trend of globalisation, this paper is focused squarely on the most fundamental and urgent problem for the twenty-first century: the relationship between man and nature. It explores this question by analyzing traditional Chinese Confucian thinking regarding the relationship between man and nature in the hope of utilizing this traditional wisdom to show in what ways traditional Chinese culture offers new insights into this and related twenty-first-century issues.
\end{abstract}

Keywords: Globalisation, Confucianism, Daoism, man, nature, Chinese culture, moral content.

\section{Chinese thinking in the context of world civilization ${ }^{\mathbf{1}}$}

About $1000 \mathrm{BC}$, the civilizations in several parts of the world all underwent a development stage that the German philosopher Karl Jaspers (1883-1969) termed a 'Philosophic Breakthrough'.

This expression indicates a sort of spiritual leap that took place in several civilizations at the beginning of the first millennium B.C., when the human mind was no longer enamoured by unknown spiritual or supernatural powers.

People started to observe and reflect upon their actual existence in the world. The major ancient civilizations, including the Hindu, the Chinese, the Judeo-Christian, and the Greek civilizations, all went

* Professor of History, National Taiwan University and research fellow, Academia Sinica.

1 This paper was not read at the conference. The author was unable to attend the proceedings. However, in view of the important observations on humanism and nature, made in the paper from a Chinese perspective, it was decided to have the paper peer reviewed, extended and then revised for publication - Editor.

2 Cf. Karl Jaspers, Michael Bullock tr., The Origin and Goal of History (New Haven: Yale University Press, 1953). 
through this development phase, in the course of which several paradigmatic personages appeared on the world stage, including Confucius (551-479 BC) in China, Siddhartha Gautama (566-486 BC) in India, and Socrates (469-399 BC) and Plato (428-348 BC) in Greece.

However, the specific 'Philosophic Breakthroughs' that took place in the development of these ancient civilizations respectively, were not the same. For example, the 'philosophic breakthroughs' of the JudeoChristian and Greek civilizations took forms and contents that differed significantly from that of Chinese civilization.

Two major differences between them lay in the fact that in the 'Philosophic Breakthroughs' of the Judeo-Christian and Greco-Roman civilizations humanism were established on the basis of the tension between man and god. The Christian concept of 'original sin' was an extension of the concept of 'fallibility of man', making man into a mere creature who seeks an eternal intimate relationship with God as the omniscient, omnipotent creator. Thus, western humanism developed out of the opposition between man and God. ${ }^{3}$ Because man and God were thought to have this intimate relationship, man had to ceaselessly manifest his servitude and confess his sins.

As for ancient Greek civilization, around 490 BC, the Greeks under Athenian leadership repelled the invading Persians at the Battle of Marathon. After this victory, the Greek city-states felt confident to expand their power militarily, and this confidence was manifested in their culture. Consequently, during the sixth and fifth centuries BC, the glorious Greek civilization was created. Socrates, Plato, Aristotle (384-322 BC) and the Greek playwrights Sophocles (496-406 BC), Euripides (480-406 BC) and Aeschylus (525-456 BC) all appeared during this period. In the classical age of Greek civilization, the spirit of humanism was also formed in the opposition between man and the gods as human destiny. For this conflict between man and God, scholars like to call this, be it the Judeo-Christian or the Greco-Roman tradition, a 'civilization of rupture'. ${ }^{4}$

In contrast, ancient Chinese civilization can best be characterized as a civilization of a 'continuum'. The philosophic breakthrough of the Chinese civilization came about because the minority of the nobility

3 I do not refer to the more differentiated view on the Roman Origin of Western humanism and the importance of the philosophical development of Stoa. Cf. Hubert Cancik, Humanismus, in Hubert Cancik, Burkhard Gladigow eds., Handbuch religionswissenschaftlicher Grundbegriffe. Vol. III (Stuttgart: Kohlhammer, 1993), pp. 173-185.

4 Cf. Zhang Guangzhi 張光直, 'Lianxu yu polie: yige wenming qiyuan xinshuo di caogao' 連續與破裂：一個文明起源新說的草稿 (Continuity and Splintering: A New Account of the Origin of Civilization), in Zhongguo qingtong shidai dierji 中國青銅時代第二集 (The Chinese Bronze Age, v. 2) (Taipei: Lianjing chuban shiyie gongsi, 1990), pp. 131143. 
held political power to manage and control the vast majority of the empire's resources, creating thereby the dazzling bronze civilization.

Because of this, China's 'philosophic breakthrough' was relatively mild, which contributes to the continuity of Chinese history, with a warm and rich intellectual heritage emerged. The most distinctive characteristic of this heritage, one that offers fresh insights for the contemporary world, is 'correlative thinking'.

This sort of thinking seeks to establish relationships between binary oppositions, interactive communications or exchanges, and finds its origin in the ancient Confucian and Daoist schools of thought, being mutually symbiotic. This sort of thinking has much to do with the ancient Chinese cosmology together with their view of mind and human nature in forming a comprehensive holistic system.

What is called 'correlative thinking'? This is an approach to thinking in which person, world and cosmos form interconnected parts in a well-knit, mutually contained intellectual continuum. Basically, it views the cosmos such that the relations among the parts and the relations between the parts and the whole manifest an organic, non-mechanistic system, in which to shake one tiny part is to move the totality. Consequently, in the cosmos, every part interacts with and influences every other; these parts also serve as interactive causes and effects of each other. This sort of 'correlative thinking' bequeathed by the ancient Chinese Confucian and Daoist intellectual traditions definitely offers some fresh indications to the contemporary world. ${ }^{5}$

The traditional Chinese 'correlative thinking' is established upon three basic themes: First, the traditional Chinese thinkers considered that all of the various phenomena in the cosmos share in a common substance. This conception appeared throughout the classics. The 'Great Appendix' to the Book of Changes points out that, underlying the different phenomena appearing among the myriad things in the cosmos, is an implicit common substance and operational logic. ${ }^{6}$

This common ground is referred to as 'de 德' (virtue, power) and 'qing 情' (fact, feeling), which depend on mankind to decipher and explicate; so there are numerous analogies among different sorts of existences and phenomena. In the YiZhoushu 逸周書, inferences are drawn from observed natural phenomena, such as the wind does not thaw the

5 I do not neglect, that in the Western tradition we can find similar elements. Cf. the famous book by Arthur O. Lovejoy, The Great Chain of Being: A Study of the History of Ideas (Cambridge: Harvard University Press, 1961). But this idea was definitely given up, when the Western historical development definitely separated in the modernization process from other civilizations.

6 Cf. Richard Wilhelm, Cary F. Baynes tr., The I Ching or Book of Changes (Princeton: Princeton University Press, 1950), pp. 280-324.

TD, 2(2), December 2006, pp. 311-330. 
ice', 'the hibernating insects do not stir', 'the fish do not swim over the ice,' to human phenomena, such as, 'the command will not work', 'the yin-qi will seduce the yang-qi', 'armor for private stores', etc. ${ }^{7}$ Dong Zhongshu 董仲舒(179-104 BC) wrote in the Chunqiu fanlu 春秋繁露:

Honor, reward, crime and punishment' ... (and) ... 'spring, summer, autumn and winter' are analogous and interactive. ${ }^{8}$

These examples reflect the deep faith of the ancient Chinese that the cosmos, the myriad things and all phenomena, share a common substance, that they therefore are continuous and analogous.

Second, because of the deep faith of the ancient Chinese that the cosmos and the myriad things share a common nature, they thought the cosmos is an organism in which a small influence can reverberate through the whole. The parts making up this cosmic organism are interpenetrating and interactive.

For example, authors of the Yizhuan 易傳 (Book of Change with commentary) had indicated that the chaotic, confusing transformations of phenomena in the cosmos all interactively influence each other:

Therefore the eight trigrams succeed one another by turns, as the firm and the yielding displace each other. ${ }^{9}$

Third, Chinese thinkers considered that not only was there the interpenetration and interaction between part and part within the cosmos, there also was an analogy relationship between the parts and the whole. Mencius (7A.4) said:

All of the ten thousand things are there, within me.

Certainly, this sentence was uttered with respect to the self-realization that accompanies moral self-cultivation, but it can be read and interpreted from another angle: it expresses that the 'I', as a part of the cosmos, also partakes of the total substance that is shared among the ten thousand things. Consequently, from the perspective of the 'I' (part), one can grasp the original substance (total substance) that is shared in common by the ten thousand things; while, from another perspective, the specific features of the ten thousand things (total substance) are reflected within the perceptions of the 'I' (part).

Therefore, the parts and the whole form a sort of interactive, interresponsive relationship. And, the parts and the whole within the

7 Jizhong Zhoushu 波冢周書 (Ji tomb Zhoushu) (i.e. Yi Zhoushu 逸周書 [Remaining Zhou documents] ) (Taipei: Shangwu yinshuguan, 1975, sibu congkan chubian suoben edition), juan 6, chap. 52, p. 33B (A refers to the upper half of the page, B the lower).

8 Su Yu 蘇輿, Chunqiu fanlu yizheng 春秋繁露義證 (Interpretation of Chunqiu fanlu) (Taipei: Heluo tushu chubanshe, 1974), juan 13, chap. 55, p.250.

9 The I Ching or Book of Changes, p. 283. 
cosmos also form a kind of revolving hermeneutical circular process.

To sum up, correlative thinking interprets the cosmos as a great system; within this system, each part is interacting and thus forming together an indivisible whole. No matter whether we trace this correlative thinking to the ancient Chinese view of a totalistic cosmogony, or to ancient Chinese Confucianism and Daoism, a holistic outlook is manifested. Additionally, this holistic cosmogony lets Chinese culture do without any western styled creation myth. ${ }^{10}$

The correlative thinking of the Chinese intellectual tradition is a connected, hierarchical intellectual approach that proceeds from theory of cosmos to theory of mind and human nature, to theory of society and rule, all clearly reflecting correlative thinking. As to cosmology or cosmogony, chapter 42 of the Dao De Jing 道德經, reads,

Tao [i.e. Dao] produced the One. The One produced the two. The two produced the three. And the three produced the ten thousand things. The ten thousand things carry the yin and embrace the yang. ${ }^{11}$

This passage clearly manifests the characteristics of correlative thinking. As to Confucian thought, in Mencius' theory of mind and human nature and theory of self-cultivation, the pathway of value and cultivation is summarized in the idea of 'expanding upon' the 'mind'. Mencius always stressed organic interactive relations among mind and body, self and society, and man and nature.

Besides cosmology and theory of mind and human nature, ancient Chinese society and socio-political theories were established on the basis of a continuum approach. The most representative example of this is the 'eight steps' of the Great Learning chapter of the Record of Rites 禮記: to investigate, to extend or attain, to make sincere, to rectify, to cultivate, to straighten, to order and bring peace to the world. These cultivation steps form a continuous process in which they are mutually implicated. ${ }^{12}$

They form a well-ordered series, which develops into a closely-knit pattern. The steps in this holistic process connect and unify the spheres of society, politics and personal self-cultivation.

10 See F.W. Mote, 'The Cosmological Gulf between China and the West', in D.C. Buxbaum and F.W. Mote ed., Transition and Permanence: Chinese History and Culture: A Festschrift in Honor of Dr. Hsiao Kung-ch'uan (Hong Kong: Cathay Press Ltd., 1972), pp. 3-22, and F.W. Mote, Intellectual Foundations of China (Cambridge, MA: The Colonial Press, 1971), Ch. 2, pp. 13-28.

11 Wing-tsit Chan, 'The Natural Way of Lao Tzu', in A Source Book in Chinese Philosophy (Princeton: Princeton University Press, 1963), p. 160.

12 Cf. Wing-tsit Chan, 'Moral and Social Programs: The Great Learning', in A Source Book in Chinese Philosophy, p. 86. 


\section{The Relationship between 'Man' and 'Nature' in Confu- cian Tradition (I): Continuity}

Based on the 'correlative thinking' in Chinese culture, traditional Chinese thinkers held that there was an intimate relationship between the natural order and the human order.

The Book of Changes points out that,

If the form of heaven is contemplated, the changes of time can be discovered.

If the form of men are contemplated, one can shape the world. ${ }^{13}$

Hence, they thought that changes in the natural order, and their implicit principles and rules, constitute the inherent structure of phenomena in human culture.

Chapter 23 of the Dao De Jing reads,

(A) whirlwind does not last a whole morning, Nor does a rainstorm day. What causes them? It is Heaven and Earth (Nature). If even Heaven and Earth cannot make them last long, How much less can man? Therefore he who follows Tao is identified with Tao. ${ }^{14}$

The ancient Daoists considered that the myriad changes taking place in the natural world, such as whirlwind, rainstorm, etc., were instructive for thinking about phenomena in human culture. This sort of analogical thinking carries the supposition of correlations between human culture and nature.

The Swiss psychoanalyst, Carl G. Jung (1875-1961), formulated and used 'the principle of synchronicity' to describe the sort of correlation, interaction and interpenetration between culture and nature expressed in the ancient Chinese thought. Influenced by this correlative pattern of thinking, traditional Chinese people always extrapolated significance in the cultural world from the natural phenomena.

The relationship between man and nature in Confucianism had two special features. The first was the continuum between culture and nature. The traditional Confucians did not take nature as something apart from the self or as an 'objective nature', with which the self has nothing to do. Rather, the traditional Confucianists had always read cultural significances into nature.

For example, Confucius said,

The human-hearted take pleasure in mountains; the wise take pleasure in rivers.

Hence, in the natural conditions of mountains and rivers, he read the

13 The I Ching or Book of Changes, p. 495.

14 Wing-tsit Chan, 'The Natural Way of Lao Tzu', in A Source Book in Chinese Philosophy, p. 151. 
human virtues of human-heartedness and wisdom. And Mencius 7A:24, reads into the natural phenomena of (water from an ample source)

going forward only after all the hollows are filled' the human cultural meaning that, 'The gentleman in his pursuit of the Way does not get there unless he achieves a beautiful pattern. ${ }^{15}$

The continuum relationship that holds between human culture and nature in Confucian tradition is manifested in two main ways: 1) the fusion of man and nature; and 2) Man adjusts to nature and improves his moral content. ${ }^{16}$

\section{The fusion of man and mature}

In Confucianism, there is a sort of developing continuum at work. When people roam at ease in nature and commune with nature, they become filled with feelings of adoration and respect for nature. One dialogue between Confucius and his students (XI.26) is particularly worthy of our attention:

When Zilu, Zengxi, Ranyou, and Gongxi Hua were seated in attendance, the Master said, 'Do not feel constrained simply because I am a little older than you are. Now you are in the habit of saying, 'My abilities are not appreciated,' but if someone did appreciate your abilities, do tell me how you would go about things.'

Zilu promptly replied, 'If I were to administer a state of a thousand chariots, situated between powerful neighbors, troubled by armed invasions and by repeated famines, I could, within three years, give the people courage and a sense of direction.'

The Master smiled at him. He then asked, 'Qiu, what about you?'

'If I were to administer an area measuring about sixty or seventy $l i$ square, or even fifty or sixty li square, I could, within three years, bring the size of the population up to an adequate level. As to the rites and music, I would leave that to abler gentlemen.'

'Chi, how about you?'

'I do not say that I already have the ability, but I am ready to learn. On ceremonial occasions in the ancestral temple or in diplomatic gatherings, I should like to assist as a minor official in charge of protocol, properly dressed in my ceremonial cap and robes.'

'Dian, how about you?'

After a few dying notes came the final chord, and then he stood up from his lute. 'I differ from the other three in my choice.'

The Master said, 'What harm is there in that? After all, each man is stating what he has set his heart upon.'

15 D.C. Lau tr., Mencius (Hong Kong: The Chinese University Press, 1979, 1984), BK VII: A, 24, p. 275.

16 D.C. Lau tr., The Analects (Hong Kong: The Chinese University Press, 1992), BK XI: 26, p. 105-107.

TD, 2(2), December 2006, pp. 311-330. 
'In late spring, after the spring clothes have been newly made, I should like, together with five or six adults and six or seven young boys, to go bathing in the River Yi and enjoy the breeze on the Rain Alter, and then go home chanting poetry.'

The Master sighed and said, 'I am all in favor of Dian.'

When the three had left, Zeng Xi stayed behind. He said, 'What do you think of what the other three said?'

'They were only stating what their hearts were set upon.'

'Why did you smile at Yu?'

'It is by the rites that a state is administered, but in the way he spoke, Yu showed a lack of modesty. That is why I smiled at him.'

'In the case of Chi, was he not concerned with a state?'

'What can justify one in saying that sixty or seventy li square or indeed fifty or sixty li square do not deserve the name of 'state'?'

'What are ceremonial occasions in the ancestral temple and diplomatic gatherings if not matters which concern rulers of feudal states? If Qiu plays only a minor part, who would be able to play a major role?'

In this dialogue between the Master and his students, Confucius does not extend particular praise to the students for having their hearts set on administrative matters. But, as to Dian's account of his longing to enjoy the rites of spring by bathing with some friends and young boys in the River Yi, then chanting poetry together on the way home, Confucius expressed his full praise by saying he was 'all in favor of Dian'. This passage is the most beautiful expression of the fusion between man and nature in Confucius' Analects. Zeng Dian 曾點 (542?475 ? BC) here expressed a feeling for the natural sphere of human life, wherein the human is fused within the natural, and praised the exquisite beauty of nature.

The immediate fusion between man and nature expressed in Confucianism reflected the organic outlook of cosmos and nature of the Confucian tradition. In the Confucian outlook, man is a part of nature; man and the dynamic motions in nature - moving, growing, soaring and diving - form an organic, indivisible holistic totality.

When observing the myriad things, the Confucians had self-attainment. The Confucians believed that four seasons flourish in succession together with humanity. In this way, the myriad things and humanity form integral parts of a seamless unity.

This Confucian attitude toward nature was deeply rooted in China's time-honoured agrarian tradition. For millennia, Chinese farmers ploughed, planted, cultivated, and harvested their crops together. They toiled and sweated together, and thereupon formed a collective economic system.

On this economic basis, the social traditions of sharing labour, 
balancing surplus and deficit, and ritual sharing developed. The Chinese scholars across the centuries expressed adoration for this sort of rural society. The Song dynasty scholars, such as Zhu Xi 朱喜(1130-1200), and the Korean Choson dynasty (1392-1911) Confucian scholars, like Yi Yulgok 李粟谷 (1536-1584), planned to use the 'village contract' model to improve life in the rural villages. In this sort of society, people enjoy amiable relations and man is filled with praise and admiration for nature. ${ }^{17}$

But, why was it that people never seemed to achieve a perfect harmony with nature in their daily life? Confucian scholars, the SongMing Neo-Confucian scholars in particular, thought that the reason why people could not achieve a perfect harmony with nature was that people were obstructed by their own excessive selfish desires. Zhu Xi interpreted the Analects 'I am all in favor of Dian' passage quoted above, as follows:

It could be said that because the Master's personal desires were completely subdued, the natural patterning operated through him and his responses were everywhere complete and without defect. Consequently, in all of his conduct, he was natural and at ease like this. And, when they spoke of their ambitions, he viewed it from his present position, to take pleasure in the common course of daily life. He had no thought of giving up his self to impress others. His living body was at ease, operating together in unison with heaven, earth and the myriad things, so that each thing realized its function and he silently realized it without words. Observing his three students' narrow focus on peripheral matters, their atmosphere was unlike his. Hence, he sighed and deeply praised Dian's sentiment. If students wanted to calculate the depth of their attainment, they could consider this to realize it. ${ }^{18}$

The Song-Ming Neo-Confucians always used the expressions 'heavenly principle' vis-á-vis 'human desire'. Inferring from Zhu Xi's commentary here, we can know that Zhu Xi considered that people must shake off their excessive selfish desires in order to return to nature and attain to the sphere in which 'heavenly principle operates through one' and in which one 'operates in unison with heaven, earth and the myriad things'. This was the sphere at which man and nature are fused in a single organic continuum.

17 The leading twentieth century New-Confucian scholar, Tang Junyi 唐君毅 (1908-1978), wrote surpassingly on the spontaneous spirit of the 'roaming mind' in Chinese culture. See, for example, his book Zhongguo renwen jingshen zhichongjian 中國人文精神之重建 (Reconstructing the Humanist Spirit) (Taibei: Zhonghua Shuju, 1982), v. 6, p. 130.

$18 \mathrm{Zhu} \mathrm{Xi}$ 朱喜 ed. and com., Lunyu jizhu論語集注 (Confucius' Analects with Collected Commentaries), in Sishu zhangju jizhu 四書章句集注 (Four Books in Chapter and Verse with Collected Commentaries) (Beijing: Zhonghua shuju, 1982), ch. 6, p. 130. 


\section{Man adjusts to nature and improves his moral content}

We can explicate this point in light of Mencius' (2A.2) discussion on his vast 'floodlike qi'. Mencius had a dialogue with Gongsun Chou on 'the heart that cannot be stirred'. ${ }^{19}$

[Gongsun Chou] asked, 'I wonder if you could tell me something about the heart that cannot be stirred, in your case and in Gaozi's case?'

[Mencius replied], 'According to Gaozi, 'If you fail to understand words, do not worry about this in your heart; and if you fail to understand in your heart, do not seek satisfaction in your qi.' It is right that one should not seek satisfaction in one's qi when one fails to understand in one's heart. But it is wrong to say that one should not worry about it in one's heart when one fails to understand words.

'The will is the commander over the qi while the qi is that which fills the body. Where the will arrives, there the qi halts. Hence, it is said, "Take hold of your will and do not abuse your qi."

'As you have already said that where the will arrives, there the qi halts, what is the point of going on to say, 'Take hold of your will and do not abuse your qi'?'

'The will, when blocked, moves the qi. On the other hand, the qi, when blocked, also moves the will. Now, stumbling and hurrying affect the qi, yet in fact palpitations of the heart are produced.'

'May I ask what your strong points are?'

[Mencius replied,] 'I have an insight into words. I am good at cultivating my "flood-like qi."

'May I ask what this 'flood-like qi' is?'

'It is difficult to explain. This is a $q i$ which is, to the highest degree, vast and unyielding. Nourish it with integrity and place no obstacle in its path and it will fill the space between Heaven and Earth. It is a qi which unites righteousness (appropriateness) with the Way. Deprive it of these, and it will collapse. It is borne of accumulated righteousness and cannot be appropriated by anyone through a sporadic show of rightness ...

In this dialogue, Mencius referred to the single substance that is shared in common by the myriad things in the cosmos-qi 弹. As a part of the natural sphere, man just needs to cultivate the qi already being inside, without 'daily chopping it down' to make 'Ox mountain become denuded,' in order to reach the sphere of the vast 'flood-like qi'. Then, on the basis of having cultivated this vast 'flood-like qi', one can reach the sphere of the mind-heart that cannot be stirred. Because of this, when Mencius faced the kings of the various states, he could look with contempt when speaking with men of consequence,' and remain unawed by the king's eminence. The vast flood-like qi cultivated by Mencius made him a resilient moral presence in the turbulent Warring States period (403-222 BC).

19 D.C. Lau tr., Mencius, II: A, 2, p. 57. 
What are the distinctive features of the vast 'flood-like qi' proposed by Mencius? The concept of qi is part of the "common discourse'20 in the world of thought in ancient China. During the past several decades, it has been the subject of intense study by Sinologists at home and overseas. 'Qi' is an age-old concept of the Chinese tradition; this concept appears mostly in documents written since the Warring States period. If we survey the use of the term 'qi' in texts of the Spring and Autumn period (722-481 BC), including recently excavated texts, such as the medical text and the 'Wuxing pian 五行篇' discovered at the Mawangdui 馬王堆 tomb in 1972, we can infer that prior to Mencius there were four main kinds of theories about $q i:^{21}$

First, there were theories concerning of the interaction between the two qi. The Yizhuan expresses this idea clearly. This sort of theories recognizes that the cosmos was formed through the sympathetic intercourse between the two qi - yin and yang 陰陽; here the cosmic significance was more prominent than the ethical significance. Second, there were theories about qi for fortune-telling. This sort of theories was closely associated with the yin-yang and five phases theories $^{22}$ that appeared during the Warring States period. During the Spring and Autumn period people had started to forecast based on auspicious and inauspicious omens using expressions like 'six qi', 'four seasons', and 'five phases'. People could even use the cloud-qi to divine and understand changes in human affairs. This was an important feature of ancient Chinese astronomy. The third sort of theories about qi concerned 'eating the qi.' Qi was recognized as an object of physical cultivation of the body. This sort of theories had a long history, originating in Shamanistic culture and practices and influenced the idea of immortals in the Warring States period. The descriptions of the art of longevity appear not only in the Daoist texts but also in newly excavated texts, like the medical text excavated from the number three Han tomb at the Mawangdui site, which discusses food-qi in the context of the art of nurturing life in elaborate detail. The fourth sort of theories about qi was the contribution of the Militarists School, who spoke of qi of high morale, cutting-qi, extending-qi, etc.

These four types of established theories about qi demonstrate that, long before Mencius, the Chinese had elaborated basic notions of qi

20 B.I. Schwartz, The World of Thought in Ancient China (Cambridge: The Belknap Press of Harvard University Press, 1985), ch. 5, pp. 173-185.

21 On the ancient Chinese notions of qi and Mencius' idea of the vast 'flood-like qi', see my Mencian Hermeneutics: A History of Interpretations in China (New Brunswick and London: Transaction Publishers, 2002), pp. 44-47.

22 The five phases or agents (wuxing, 五行) including Metal, Wood, Water, Fire, and Earth that rotate to succeed one another in the universe. Zou Yan 鄒衍 (305-240 B.C.?) is often mentioned as the representative thinker of this school. Cf. Wing-tsit Chan, $A$ Source Book in Chinese Philosophy, pp. 244-245.

TD, 2(2), December 2006, pp. 311-330. 
and developed the idea of cosmic qi. In Mencius' hands, he infused the idea of qi with moral significance. The turn from the archaic Chinese discourses on qi to Mencius' expression of the vast 'flood-like qi' was the first major turning point in the history of the Chinese conception of qi. From this turning point, we can see that Mencius' reflections on human life were deeply infused with historical meaning.

Mencius pointed out that human life can be divided in several levels, including 'mind-heart', ' $q i$ ', and 'physical form'. Indeed, Mencius recognized that 'mind-heart' and 'qi' were mutually formed and related; but 'mind' played a more fundamental role in Mencius' philosophy of man.

He saw the value consciousness of mind as universal, anyone who sees a baby about to crawl into a well will naturally feel alarm and concern. This is a key difference between humans and animals. Although human 'mind' bears this sort of 'innate knowledge of the good' and 'inborn capacity to do good', it is inseparable from a person's qi. Without making efforts to nurture this qi, one's apriori inborn inclination towards good will gradually atrophies and one's conduct will become desire-driven.

While 'mind-heart' was universal to everyone, it is prior to qi. One who steadily and continuously nurtures the mind-heart would refine the $q i$ and transform the entire person. This would be most evident in the transforming of one's bearing and attitude, which Mencius referred to as 'giving one's body complete fulfilment' (7A:38) manner or disposition. A virtuous scholar whose language and action were penetrated by the vast flood-like qi would display a transformation in his manner and disposition.

Mencius said that if you intend to observe a certain person, the best way would be to watch his eyes. A well-cultivated person just needs to read the spirit in a person's eyes in order to determine the quality of that person's character. Mencius probed the content of human life deeply and precisely, and came up with a holistic perspective. Mencius emphasized that the 'mind-heart' that has been transformed by penetrating the vast 'flood-like qi' can influence the person's physical form; from this, he indicated his theory of 'giving one's body complete fulfilment.' Such theory was deeply related to the correlative thinking characteristic of Chinese culture.

Mencius emphasized the continuity between man and nature. He considered that man and nature were neither opposed nor separated. There are 'nature' contained many implicit meanings, faiths and values in nature; in fact, they were all implicit in man's mind-heart, so that the more a person conducts self-reflection the more he would be able to rise to commune with nature, and able to comprehend where the implicit meanings lie in the cosmos and nature. In saying, 'For a 
man to give full realization to his heart is for him to understand his own nature, and a man who knows his own nature will know Heaven,' (7A: 1$)^{23}$ Mencius established the continuity and lack of separation between the sphere of culture and the sphere of nature.

Nonetheless, while stressing the ancient Chinese view of the continuity between man and nature, there was one important Confucian thinker we must not neglect: Xunzi 荀子 (c.298-238 BC). Xunzi regarded human nature as just natural appetites and strongly emphasized that the fruits of 'culture' are the result of overcoming 'nature' in that sense.

Xunzi's cutting off of the continuum between man and nature espoused by traditional Confucianism was a major twist in the ancient Confucian view of nature. For Xunzi, human nature meant that, 'when hungry, one desires to eat; when cold, one desires warmth; when exhausted, one desires rest,' hence he discarded the idea of a positive, general nature of man. In his essay, 'Of Honor and Disgrace,' Xunzi wrote:

All men possess one and the same nature: when hungry, they desire food; when cold, they desire to be warm; when exhausted from toil, they desire rest; and they all desire benefit and hate harm. Such is the nature that men are born possessing. They do not have to await development before they become so. It is the same in the case of a Yu and in that of a Jie. They eye distinguishes white from black, the beautiful from the ugly. The ear distinguishes sounds and tones as to their shrillness or sonority. The mouth distinguishes the sour and salty, the sweet and bitter. The nose distinguishes perfumes and fragrances, rancid and fetid odors. The bones, flesh, and skinlines distinguish hot and cold, pain and itching. These, too, are part of the nature that man is born possessing, that he does not have to develop, and that is true of both $\mathrm{Yu}$ and Jie. ${ }^{24}$

Whether a man can become a Yao or Yu or be a Jie or Robber Zhi, whether he becomes a workman or artisan, a farmer or merchant, lies entirely with the accumulated effect of circumstances, with what they concentrate on in laying their plans, and on the influence of habits and customs. If one becomes a Yao or Yu, one normally enjoys tranquility and honor; if one is a Jie or Robber Zhi, one normally falls into peril and disgrace. If one becomes a Yao or Yu, one constantly finds enjoyment and ease; if one becomes a workman, artisan, farmer, or merchant, one must constantly toil and trouble oneself. Though this is so, many men are like the latter, but only a few men are like the former.

Why should this be so? I say that it is because they remain uncultivated; even Yao and Yu were not born wholly what they became, but rose up by transforming their old selves, brought them to perfection

23 D.C. Lau, tr., Mencius, 7A:1, vol. 2, p. 265.

24 John Knoblock, Xunzi, A Translation and Study of the Complete Works (Standford University Press, 1990), vol. 1, BK4, 'Of honor and Disgrace', pp. 191-192.

TD, 2(2), December 2006, pp. 311-330. 
through cultivation and conscious exertion, and only after first putting forth the utmost effort did they become complete. ${ }^{25}$

Xunzi considered that man was born with a fondness for gain, with the desires of the eyes and ears, such that he required aposteriori refolding and reforming. Xunzi's essay, 'Man's Nature is Evil,' reads:

\begin{abstract}
Human nature is evil, any good in human is acquired by conscious exertion. Now, the nature of man is such that he is born with a love of profit. Following this nature will cause its aggressiveness, and greedy tendencies to grow and courtesy and deference to disappear. Human are born with feelings of envy and hatred. Indulging these feelings causes violence, and crime to develop and loyalty and trustworthiness to perish. Man is born possessing the desires of the ears and eyes (which are fond of sounds and colors). Indulging these desires causes dissolute and wanton behavior to result and ritual and moral principles, precepts of good form, and the natural order of reason to perish. ${ }^{26}$
\end{abstract}

This being the case, when each person follows his inborn nature and indulges his natural inclinations, aggressiveness and greed are certain to develop. This is accompanied by violation of social class distinctions and throws the natural order into anarchy, resulting in a cruel tyranny. Thus, it is necessary that man's nature undergo the transforming influence of a teacher and the model and that he guided by ritual and moral principles. Only after this has been accomplished do courtesy and deference develop. Unite these qualities with precepts of good form and reason, and the result is an age of orderly government. If we consider the implications of these facts, it is plain that human nature is evil and that any good in humans is acquired by conscious exertion.

In summary, Xunzi strongly emphasized that 'culture' had to overcome and remold 'nature'. Man must use the aposteriori to reform the apriori in order to avoid the natural human from taking hold and conducing to evil. In the worlds of thought in Confucius and Mencius, 'Man' and 'Nature' formed a continuum. By Xunzi's hand, the continuity was splintered.

\title{
III. The relationship between 'Man' and 'Nature' in Confu- cian thought: a monistic view
}

The second special feature of the Confucian view of man and nature is that 'man' and 'nature' form a unity. This sort of monistic view supposes that 'man' and 'nature' share a substance and pattern or principle in common: Ren 仁 (benevolence).

25 The legendary emperors Yao 堯, Shun 舜, Yu 禹 were mentioned in the Confucian classics as the 'sage-kings' of the golden era in archaic China when everything was perfectly in order and flourished according to the seasons. It was the Garden of Eden in Chinese history that aroused nostalgia of many Confucianists. Jie 桀 and the Robber Zhi 跖 were the representative figures of evil personalities in that period.

26 John Knoblock, Xunzi,BK23, 'Man's Nature is Evil', pp. 150-151. 
Ever since early antiquity, the idea that 'man' was produced by 'nature' was no stranger to Chinese culture. In the Spring and Autumn period text Guanzi 管子, the 'Rivers and Land' chapter (shuidi 水地) reads: 'Land is the origin of the myriad creatures, the fertile root of all the species. Rivers are the blood-qi of the land, which flow through the sinews and channels (of the terrain). ${ }^{27}$ This passage illustrates the notion of organic production in early Chinese thought.

The view that 'man' and 'nature' form a unity in classical Confucianism was manifested clearly in Mencius. Mencius said,

All the ten thousand things are there in me. There is no greater joy for me than to find, on self-examination, that I am true to myself. Try your best to treat others as you would wish to be treated yourself, and you will find that this is the shortest way to benevolence. (7A:4) ${ }^{28}$

While Mencius' term 'all things' is open to several interpretations, there should be little dispute that it refers to the natural myriad things in the world. Zhu Xi explicated this passage from Mencius as follows:

This chapter affirms that the li (principles) of the myriad things are all contained within me. To realize this by embodying them is said to be the great joy of examining oneself and being sincere.' To practice it according to empathy then is beyond the capacity of the private but can be realized through jen. ${ }^{29}$

According to Zhu Xi's interpretation, the reason that the myriad things can form a unity with one is because the $l i$ of the myriad things are contained within oneself, that is to say, 'man' and 'nature' share principle and substance in common.

In the eleventh century, Zhang Zai 張載 (Hengqu 横渠, 1020-77) gave an even more vivid account of the relationship between 'man' and 'nature' in his essay, 'Ximing 西銘' (Western Inscription):

Heaven is my father and Earth is my mother, and such an small creature as I finds a place in their midst.

Therefore, that which fills the cosmos I regard as my own body andthat which guides the cosmos I regard as my original nature.

All people are my brothers and sisters, and all things are my companions.

The emperor is the eldest son of my parents (Heaven and Earth), and the great ministers are his stewards. Respect the aged - this is the way to treat them as elders should be treated. Show deep love toward the orphaned and the weak - this is the way to treat them as the young should be treated. The sage identifies his character with that of Heaven and Earth, and the worthy is the most outstanding man. Even those who are tired, infirm, crippled or sick, and those who have no brothers or children, wives or husbands, are all my brothers who are in distress and have no one to turn to. ${ }^{30}$

27 'Shuidi' 水地 (Water and Land) in Guan Zi 管子 (Taipei: Shangwu yinshuguan, 1975, sibu congkan chubian suoben edition), juan 14, chap. 39, p. 84A.

28 Mencius, 7A:4, vol. 2, p. 265.

29 Zhu Xi, 'Mengzi jizhu' in Sishu zhangju jizhu (Beijing: Zhonghua, 1982), ch. 13, p. 350.

30 English translation adapted from Wing-tsit Chan trans. and comp., A Source Book in Chinese Philosophy (Princeton: Princeton University Press, 1963), p. 497. 
Zhang Zai followed along in Mencius' stream, pointing out that even things are also companions of man, such that a person, other people or even the natural myriad things form a unity with oneself.

How is it possible for 'man' and 'nature' to form a unity? The brothers Cheng Hao 程影 (Mingdao 明道, 1032-85) and Cheng Yi 程頣 (Yichuan 伊川, 1033-1107) offered an answer to this question:

'On Understanding the Nature of Ren'

The student must first of all understand the nature of ren. The man of ren
forms a unity with all things without any differentiation. Appropriateness,
ritual propriety, wisdom and fidelity are all expressions of ren.

[One's duty] is to understand this $l i$ (pattern, principle) and preserve ren with sincerity and reverence, that is all. There is no need for caution and control. Nor is there any need for exhaustive search. Caution is necessary when one is mentally negligent, but if one is not negligent, what is the necessity for caution? Exhaustive search is necessary when one has not understood $l i$, but if one preserves ren long enough, $l i$ will naturally dawn on him. Why should he have to depend on exhaustive search? ${ }^{31}$

Nothing can equal to this Way. It is so vast that nothing can adequately explain it. All of the operations in the cosmos are our operations. Mencius said that, 'All things are already complete within oneself' and that 'one must examine oneself and be sincere' and only then will one experience great joy. If one examines oneself and finds that one is not yet sincere, it means that there is still an opposition between the two (self and nonself). Even if one tries to identify the self with the none self, one will not achieve a unity. How then can one experience joy?

The purpose of Zhang Zai's 'Western Inscription' was to explain this substance (of complete unity) fully. If one preserves ren with this idea in mind, what more is there to be done? 'Always be doing something without expectation. Let the mind not forget its objective, but let there be no artificial effort to help it to grow.' Not the slightest effort is exerted! This is precisely the way to preserve ren. When ren is preserved, self and other are identified.

For our inborn discernment of goodness and inborn capacity to carry it out are originally not lost. However, because we have not gotten rid of the heart-mind dominated by habits, we must preserve and exercise our original mind, and in time old habits will be overcome. This matter is extremely simple: the only danger is that people will not be able to hold on to it. But if we practice it and enjoy it, there need be no worry of our being unable to hold it.

In this passage, Cheng Hao pointed out clearly that the man of ren (benevolence, humanity) forms a unity with the myriad things without differentiation, stressing that appropriateness, ritual propriety,

31 Ibid., pp. $523 f$. 
wisdom, fidelity, etc., as both moral conduct and value concepts are all expressions of ren. People just need to reflect deeply within to discern the content of ren and reach the sphere that Mencius called becoming 'sincere through self-reflection'. At this level, one comprehends that self and other are not opposed, not separate.

The great synthesizer of the twelfth century, Zhu Xi (1130-1200) wrote in his essay 'Treatise on Ren' (Renshuo 仁說):

The mind of Heaven and Earth is to produce things. ${ }^{32}$

In the production of man and things, they receive the mind of Heaven and Earth as their own mind. Therefore, with reference to the character of mind, although it embraces and penetrates all and leaves nothing to be desired, nevertheless, one word will cover all of it, namely, ren (humanity).

On this account, the entire cosmos is filled through and through with a ceaselessly dynamic spirit, and 'man' and the 'myriad things' in the cosmos each receive their portion of the core value of ceaseless production and reproduction when they are produced and grow up. The common core value of this cosmos is none other than ren.

In the fifteenth and sixteenth centuries appeared the Confucian philosopher, Wang Yangming 王陽明 (Shouren 守仁, 1472-1529). Although he had differences with Zhu Xi in doctrine and approach, regarding the proposition that 'self and other form a unity,' he was in basic agreement with Zhu. In the essay, 'Inquiry on the Great Learning' (Daxue wen 大學問), Wang wrote:

Question: The Great Learning was considered by a former scholar (Zhu Xi) to be the learning of a great man. I venture to ask why the learning of a great man should consist in 'manifesting bright virtue'?

Master Wang said: The great man regards Heaven, Earth and the myriad things as a unity. He regards the world as one family and the country as one person. As to those who make a division between things and distinguish between self and others, they are small men. That the great man can regard Heaven, Earth and the myriad things as a unity is not because he deliberately wants to do so, but it is natural to the benevolent nature of his mind to do so. Forming a unity with Heaven, Earth and the myriad things is true not only of the great man. Even the mind of the small man is no different. Only he himself makes it small. Therefore, when he sees an infant about to fall into a well, he cannot help but feel alarm and commiseration. This shows that his benevolence forms a unity with that infant. It might be objected that the infant belongs to the same species. Again, when he observes the pitiful cries and frightened appearance of birds and beasts about to be slaughtered, he cannot help but feel an 'inability to bear' their suffering. This shows that his benevolence forms a unity with those birds and beasts. It might be objected that those birds and beasts are sentient beings as he is. But when he sees plants broken and destroyed, he cannot help but feel pity for them.

32 Ibid., 593f.

TD, 2(2), December 2006, pp. 311-330. 
This shows that his benevolence will form a unity with even plants. It might be said that plants are living beings as he is. Yet even when he sees tiles and stones shattered and crushed. He cannot help but feel regret. This shows that his benevolence forms a unity with even those tiles and stones. This means that even the mind of a small man necessarily has the benevolence that forms a unity with all things. Such a mind is rooted in his heavenlyendowed nature, and is naturally intelligent, clear and not beclouded. For this reason, it is called the 'bright virtue'. Although the mind of the small man is divided and narrow, yet his benevolence that forms a unity can remain free of darkness to this degree. This would be due to the fact that his mind has not yet been aroused by desires or obscured by excessive selfishness. When it is aroused by desires and obscured by excessive selfishness, compelled by greed for gain or fear of harm, and stirred by anger, he will destroy things, kill members of his own species, and will do anything. In extreme cases, he will slaughter even his own brothers, and the benevolence that forms a unity will disappear from him completely. Hence, if it is not obscured by excessive selfish desires, even the mind of the small man has the benevolence that forms a unity with all things, just as does the mind of the great man. As soon it is obscured by excessive selfish desires, even the mind of the great man will become divided and narrow like the mind of the small man. Thus, the learning of the great man consists entirely in getting rid of the obscuration of excessive selfish desires in order by his own efforts to make manifest his bright virtue, so as to restore the condition of forming a unity with Heaven, Earth and the myriad things, a condition that is originally so, that is all. It is not that outside of the original substance something else can be added..$^{33}$

Wang Yangming took Zhu Xi's opinion that the Great Learning was the learning of the great man one step further by asking,

Why should the learning of the great man consist in manifesting the bright virtue?

Wang pointed out that the great man is the one who 'forms a unity with Heaven, Earth and the myriad things.' And, the reason why the great man is able to form such a unity is because the mind of the great man takes ren as its essential substance. Because of this, he experiences no separation from even the plant, trees, birds or beasts.

Moreover, people just need to get rid of their excessive selfish desires and be less self-centred, in order to fully release and develop their inner goodness (based on ren or bright virtue) and be able to reach the sphere of forming a unity with the myriad things.

In Confucius' Analects, Zeng Dian indicated a sphere in which 'man' and 'nature' are fused. From the eleventh century on, while Zhang Zai, the two Cheng brothers, Zhu Xi and Wang Yangming all agreed about the sphere at which 'man' and 'nature' are fused as a unity, they also had subtle differences.

As to Zeng Dian's spiritual realm, he maintained that one who is free of the pressure of subjective oppositions will naturally experience the

33 Ibid., 659f. 
harmony of self and other forming a unity. For him,

natural myriad things will no longer be objects of human intention, desire, knowledge or discrimination, and he will return to himself as a condition of his self-realization. ${ }^{34}$

The unity spoken of by the pre-Qin Confucians had a richer aesthetic flavour, so they would say that on a beautiful spring morning, self and object would both be forgotten, and one would spontaneously experience self-attainment. ${ }^{35}$ Compared to the pre-Qin view of the unity between self and object, the Song-Ming Neo-Confucians held that the unity of self and object contained deep moral content. In their accounts, the beauty of the unity of 'man' and 'nature' is based on the goodness of 'ceaseless production and reproduction' at the core. ${ }^{36}$

\section{Conclusion}

The Confucian tradition is the time-honoured mainstream of Chinese culture, and in this mainstream man and nature are perceived as somehow fused and having an interactive symbiotic relationship. 'Nature' is the Creator of 'Man', and 'Man' is a Participant in 'Nature'. The possibility of continuity and unity between man and nature is premised squarely on the 'ceaseless production and reproduction' of the ren that they share in common. 'Ren' is inherent in the mind-heart of each person, and yet it transcends each specific individual person to form the common substance shared by heaven, earth and the myriad things. In Confucian thinking, the establishment and development of the continuity and unity of man and nature are based on the selfrealization of each person's heart-mind.

The view that man and nature are continuous and form a unity in the Confucian tradition, has a profound contemporary relevance. Since the beginning of the Industrial Revolution, industrial civilization and the associated capitalist culture have been spreading around the world for the past two centuries, promoting what we might call a 'civilization of rupture'. The splintering of modern civilization begins with the splintering off of individual man from the common substance of the cos-

34 Zhang Heng 張亭, 'Lunyu zhong di yishoushi'《論語》中的一首詩 (A Poem in the Analects), in Zhang Heng, Shiwen zhiji lunji 詩文之際論集 (Collected Essays on Thought and Literature: A Contemporary Interpretation of Confucianism and Daoism) (Taipei: Yuncheng, 1997), p. 486.

35 Cf. Philip J. Ivanhoe, 'Early Confucianism and Environmental Ethics', in Mary Evelyn Tucker and John Berthrong eds., Confucianism and Ecology: The Interaction of Heaven, Earth, and Humans (Cambridge, Mass.: Harvard University Center for the Study of World Religions, 1998), pp. 37-58.

36 Cf. Michael C. Kalton, 'Extending the Neo-Confucian Tradition: Questions and Reconceptualization for the Twenty-First Century', in Tucker and Berthrong eds., Op. cit., pp. 77-104. 
mos. The Faustian spirit, which Johann Wolfgang von Goethe (17491832) described in his classic drama, Faust, shows some characteristics of contemporary civilization by portraying man as seeking to be the master of the world, seeking to harness and exploit the energy and resources of the world for his own purposes. The contemporary realization of the Faustian spirit has become increasingly fierce, but remains lacking in any sort of redeeming transcendent moorings.

The second manifestation of the rupture in modern civilization lies in the division between man and nature. After the Industrial Revolution, the relationship between man and nature has become a divided, antagonistic relationship. Man started to over-exploit the resources offered by nature, to produce all sorts of collateral environmental pollution of the air, the water, the land, etc. In the past several decades, nature's counter-attacks have manifested warnings to humanity not to over-exploit natural resources and poison the springs of life. Modern civilization, which is based on exploiting and using natural resources, stresses that growth is the fundamental strategy for prosperity; but mankind's relentless application of this strategy is producing a series of major disasters - mankind is doing this almost unconsciously and thus remains largely unwilling to accept responsibility.

The third manifestation of the rupture in modern civilization lies in the division between man and society. In modern society, the feelings of separation and alienation between people grow deeper by the day. Individuals no longer draw upon shared values of their putative society. The subjective, isolated individual of contemporary society has an excessive sense of sovereign individualism, which makes him or her become ever more isolated and solitary. The addition of the feeling of alienation makes modern man not only ceaselessly feel depressed, but now when facing the ultimate questions of life he flounders ever more helplessly.

The continuity and unity between man and nature held by the Confucian tradition expresses the hope that, between man and cosmos, a harmonious relationship can be established; namely, surveying the transcendental substance that underlies man and nature alike, there is hope that an interactive symbiotic relationship can be established; working between the individual and society, there is hope that a shared sense of common esteem, common concern can be established. 